Western University

Scholarship@Western

Aboriginal Policy Research Consortium International (APRCi)

6-2011

\title{
Kanyininpa (Holding): A Way of Nurturing Children in Aboriginal Australia
}

Fiona Ryan

Follow this and additional works at: https://ir.lib.uwo.ca/aprci

Part of the Other Education Commons

Citation of this paper:

Ryan, Fiona, "Kanyininpa (Holding): A Way of Nurturing Children in Aboriginal Australia" (2011). Aboriginal Policy Research Consortium International (APRCi). 373.

https://ir.lib.uwo.ca/aprci/373 
This article was downloaded by: [University of Western Ontario]

On: 21 December 2012, At: 11:45

Publisher: Routledge

Informa Ltd Registered in England and Wales Registered Number: 1072954 Registered

office: Mortimer House, 37-41 Mortimer Street, London W1T 3J H, UK

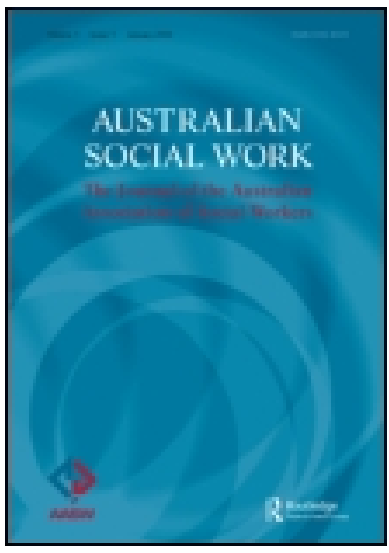

\title{
Australian Social Work
}

Publication details, including instructions for authors and subscription information: http:// www.tandfonline.com/loi/ rasw20

\section{Kanyininpa (Holding): A Way of Nurturing Children in Aboriginal Australia}

\author{
Fiona Ryan ${ }^{a}$ \\ a University of South Australia, Australian Centre for Child \\ Protection, Adelaide, South Australia, Australia \\ Version of record first published: 09 J un 2011.
}

To cite this article: Fiona Ryan (2011): Kanyininpa (Holding): A Way of Nurturing Children in Aboriginal Australia, Australian Social Work, 64:2, 183-197

To link to this article: http:// dx.doi.org/ 10.1080/ 0312407X. 2011.581300

\section{PLEASE SCROLL DOWN FOR ARTICLE}

Full terms and conditions of use: http://www.tandfonline.com/page/terms-andconditions

This article may be used for research, teaching, and private study purposes. Any substantial or systematic reproduction, redistribution, reselling, loan, sub-licensing, systematic supply, or distribution in any form to anyone is expressly forbidden.

The publisher does not give any warranty express or implied or make any representation that the contents will be complete or accurate or up to date. The accuracy of any instructions, formulae, and drug doses should be independently verified with primary sources. The publisher shall not be liable for any loss, actions, claims, proceedings, demand, or costs or damages whatsoever or howsoever caused arising directly or indirectly in connection with or arising out of the use of this material. 


\title{
Kanyininpa (Holding): A Way of Nurturing Children in Aboriginal Australia
}

\section{Fiona Ryan}

University of South Australia, Australian Centre for Child Protection, Adelaide, South Australia, Australia

\begin{abstract}
This paper discusses aspects of traditional Australian Aboriginal nurturance of infants, children, and young people through an exploration of the meaning of certain words selected from Central and Western Desert Aboriginal languages. Connections are drawn between this traditional form of child rearing and Bowlby's theory of attachment. Aspects of traditional Aboriginal methods of nurturing infants, children, and young people, which have been retained in contemporary Aboriginal child-rearing practices, are also explored. Practitioners, policy makers, and researchers in child protection are encouraged to listen to Aboriginal people, and through listening and reflecting on their own practice, to identify and work with the strengths in Aboriginal child-rearing models, values, and practices.
\end{abstract}

Keywords: Australian Aboriginal; Attachment Theory; Child Protection; Cultural Competence; Assessment

In 2007, at a summit for Aboriginal child protection workers in Western Australia, participants questioned the impact of interventions in Aboriginal communities on the basis that they lacked "involvement in professional practice of a context-specific and culturally-informed knowledge of child protection" (Bessarab \& Crawford, 2010, p. 191). One Aboriginal participant stated

I know there is a lot of bad out there but we also need to look at the good things and what families and kids are doing well. What enables them to be the way they are and we can learn from them instead of always looking at the deficits. (Bessarab \& Crawford, 2010, p. 192)

How might non Indigenous practitioners, researchers, and policy makers "widen the lens" that we see through to really take account of Indigenous contexts, to see their strengths, and support them? How might we reflect on our own values and models and recognise the values and strengths of the models in Aboriginal cultures? Aboriginal participants at the summit acknowledged that it can be difficult, particularly for non

Correspondence to: Ms Fiona Ryan E-mail: ryderyan@chariot.net.au Accepted 12 April 2011 
Aboriginal workers, to negotiate the complexity of the Indigenous context. However, they pointed out that this could be made easier by seeking out and including the experiences and knowledge of Aboriginal workers in the process of making decisions around child protection issues for Indigenous families and children. Many Aboriginal workers at the summit expressed disappointment at the general lack of openness among non Aboriginal staff to listen to what they and their communities had to say about the protection of children. In the words of a non Aboriginal participant at the summit, to be open to the views of Aboriginal people might require non Aboriginal people to learn to "sit with uncertainty, confusion, and let trust in the process carry us through" (Bessarab \& Crawford, 2010, p. 189).

This paper, written by a "white" researcher, draws on my work background with Aboriginal communities and my academic background in applied linguistics and Aboriginal studies. I am not a practitioner in child protection. The multidisciplinary research, which I have been able to be a part of within the Australian Centre for Child Protection, has the potential to offer practitioners and others a perspective that goes beyond the familiar, to make connections between disciplines, and to provide new insights for consideration. Non Aboriginal people cannot fully know an Aboriginal perspective but we can seek to understand it more fully.

To listen - kulini in the Pitjantjatjara language - also means "to understand". If a person does not listen or understand, Pitjantjatjara people call that person pina pati, which literally means "closed ears" but can also be understood as deaf, unable to understand, or even stupid. Aboriginal people would like non Aboriginal people to listen to, learn from, and engage with Aboriginal people and their perspectives and knowledgebase, as well as to engage in imparting Western knowledge to them (Bessarab \& Crawford, 2010; Priest, King, Nungarrayi Brown, Nangala, \& Nangala, 2007; Warrki Jarrinjaku Aboriginal Child Rearing Strategy [ACRS] Project Team, 2002). In the Warrki Jarrinjaku Aboriginal Child Rearing Strategy (2002), Indigenous women highlighted the need for Indigenous and non Indigenous people to work together in a "both ways" approach, which they believed can happen when people listen deeply and respectfully to one another, care for each other, and take time to build relationships. This is an important aspect of working with Aboriginal people and can easily be overlooked by Western services and departments as being too time consuming and costly. However, this "both ways" approach forms the foundation for improved provision of services for Aboriginal communities, families, and ultimately for children.

The traumatic and ongoing effects of colonisation have placed constraints on the ability of Aboriginal people to maintain their traditional ways of caring for their children. Ongoing social and economic inequity and power imbalances have also affected the life chances of Indigenous peoples, and they continue to contribute to Indigenous child abuse and neglect, and intergenerational trauma through alcohol and drug abuse, poverty, overcrowding, and inadequate housing. Child protection statistics have highlighted a growth in child protection notifications for Australian children, particularly for Australian Indigenous children. Indigenous children aged 0-16 years have been grossly over-represented in the child protection system in all 
Australian states and territories and are 7.5 times more likely to be the subject of a substantiated report of child maltreatment and 9 times more likely to be in State care than other Australian children (Berlyn \& Bromfield, 2010).

The desire of parents, communities, and societies to provide children with emotional and physical security, happiness, and confidence in themselves and their communities, and in the wider world is generally considered to be universal. It is also generally believed that the achievement of this goal will enable children to grow into competent adults, who can nurture and care for future generations. Some particular aspects of child-rearing are also regarded as universal, such as the need for an emotional bond with a caregiver or caregivers, the need for security and protection, and the need for growing emotional competence (Posada, 2000). How children are reared to achieve this bond can be quite diverse across cultures.

This paper focuses on the strengths that may be found in Aboriginal child-rearing practices and takes a "both ways" approach to discussing the nurturance of children. The paper begins with a brief overview of Western attachment theory, followed by a critique of the applicability of attachment theory to Aboriginal contexts according to the existing literature. A culturally competent alternate to the Western model of attachment is then presented through an exploration of the traditional Aboriginal construct of "kanyirninpa" or "holding", which is the way that Aboriginal people from the Central and Western Desert regions of Australia have nurtured their infants, children, and young people into adulthood for thousands of years. Kanyirninpa and its related traditional child-rearing practices may still be informing culturally-specific approaches to raising children in contemporary Aboriginal situations in both urban and remote regions of Australia.

The aim of this paper is to offer a small widening of the lens to highlight the strengths in Aboriginal nurturance of children, which is a perspective that can sometimes be difficult for practitioners to see when they are immersed in child protection cases.

\section{Theoretical Framework}

\section{Attachment Theory}

In child protection practice, the child-caregiver relationship is usually assessed as part of determining the safety and wellbeing of children within the family. Attachment has been described as a bond that provides an enduring emotional relationship with a particular person, providing safety, comfort, soothing, and pleasure (Perry, 2001). The loss of this relationship evokes severe distress. The relationship has generally been viewed as a mother-child relationship. Bowlby (1969), the originator of attachment theory, defined the attachment relationship as either secure or insecure. A primary caregiver, who is physically and emotionally available and responsive to an infant and young child, is thought to provide a secure attachment for the child and this "secure base" that the caregiver provides is thought to enable the child's capacity for safe exploration and learning. A carer who is inconsistently responsive to a child, but in relatively predictable ways, is thought to 
produce an insecure-avoidant or insecure-ambivalent attachment style in the child. A disorganised attachment style, where a child responds to a primary caregiver in a confused, chaotic, or fearful manner, can also be evoked in a child when a parent is at times a source of comfort to the child and at other times a source of fear. Children with disorganised attachment patterns are thought to be at highest risk for future developmental disorders and this attachment style may also indicate that they have experienced maltreatment in the past. According to this theory, the absence of an important primary caregiver relationship or the presence of a disorganised attachment style can lead to emotional and behavioural problems throughout a person's life and can affect their ability to form healthy relationships with others. In addition to the relationship with the primary caregiver, infants may develop a hierarchy of attachments with other people who provide additional experiences of safety and nurturing (Jordan \& Sketchley, 2009). The hierarchical order of these relationships develops in terms of availability of these other carers and the infant's ability to develop these further relationships is enhanced if the infant has a secure attachment with their primary caregiver.

There has been much debate about the applicability of the core hypotheses of attachment theory across cultures. Rothbaum, Weisz, Pott, Miyake, and Morelli (2000) argued that attachment theory is deeply rooted in mainstream Western thought. Referring to Japanese society, which is communally oriented and emphasises strong extended-family networks, these authors disputed the universality of the mother-child relationship as the crucial base of all relationships. Posada (2002) disagreed, arguing that the secure-base hypothesis persists across cultures, but need not be restricted to one primary caregiver. Brown, Hawkins Rodgers, and Kapadia (2008) recognised the benefit of attachment theory in providing a framework for diagnosis and treatment but wanted to see further application of multicultural information in order to enlarge clinicians' views and assessments of children's attachments. Minuchin (2002) suggested the need for greater exploration of the conditions in which children make strong attachments almost from birth with multiple caregivers, positing that the association of multiple caregiving with healthy development could provide an important contribution to research on attachment. She cautioned against using the nuclear family as a standard for evaluating attachment, and saw value in alternative family structures being taken into greater account.

\section{Attachment Theory and Aboriginal Cultures}

With reference to Aboriginal cultures in Australia, arguments about multiple caregivers, alternative family structures, and relevance of core hypotheses of attachment theory to different situations need to be reconsidered. A study conducted in New South Wales, Australia, has questioned the appropriateness of attachment assessments for assessing Aboriginal children's security, Aboriginal caregivers' sensitivity towards their children, and their children's development of competence within child protection practice (Yeo, 2003). Yeo raised concerns that Aboriginal children will continue to be 
removed from their families if assessments do not include broader community factors, including historical, cultural, and spiritual values. Yeo (2003) considered that the basic premise of attachment theory, wherein an infant seeks proximity to caregivers for protection and care, to be universal, but gave examples of differences in the patterns of sensitivity and responsiveness of caregivers to their children. Yeo (2003) incorporated Aboriginal caregiving values within the three core hypotheses of attachment theory, which have been elaborated upon in the cross cultural context by Rothbaum et al. (2000) and van Ijzendoorn \& Sagi (1999).

Responding to the first core hypothesis that "the caregiver who is sensitive to the child will achieve a secure attachment" (Rothbaum et al., 2000), Yeo (2003, p. 296) suggested that one way in which sensitivity is expressed towards infants in Aboriginal culture is through anticipating their needs and minimising their expression of distress. Here, anticipation contrasts with the stated hypothesis of attachment theory, namely that the sensitive caregiver, usually the mother, responds to the child's distress signals of danger and needs for security. Yeo (2003) also found that Aboriginal infants and children may have a number of regular female attachment figures, providing enduring relationships of support into adulthood. Multiple mothering was found to be the most common pattern for raising infants and children in Koorie society in Victoria, Australia (Atkinson \& Swain, 1999), as well as in the Central and Western Deserts and Arnhem Land, although the biological mother in these studies still played the central role in the care of her child (Berndt \& Berndt, 1981; Hamilton, 1981). Posada (2002) argued that variability in the sensitivity behaviours of caregiving across cultures can be expected. The key issue is whether or not sensitivity and security are related. In the case of the sensitivity behaviours of Aboriginal caregivers as outlined by Yeo (2003), it would appear that they are related to security.

The second hypothesis is that "secure attachment results in social competence as a child and as an adult" (Yeo, 2003, p. 296). This assumption is based on Western views of competence in terms of: (a) exploration; (b) self-expression and affect regulation; (c) sociability; and (d) competence in adulthood. According to this view, the values that define competence are autonomy, ego resilience, and persistence in problem solving. However, for the Aboriginal participants in Yeo's (2003) study, values of interdependence, group cohesion, spiritual connectedness, traditional links to the land, community loyalty, and interassistance were common indicators of social and emotional competence. One's own autonomy, self-expression, and affect regulation were only important in as much as they supported group cohesion and connectedness. Malin, Campbell, and Agius's (1996) study of an Adelaide Aboriginal Nunga woman's parenting, and Hamilton's (1981) study of Anbarra parenting in Arnhem Land supported these aspects of community loyalty, interdependence, and interassistance with regard to values and behaviours to which parents aspire and seek to model for their children. Although cultures may view competence differently, to be competent within one's own culture is regarded as desirable.

The third hypothesis is that children who are securely attached use the primary caregiver as a secure base for exploring the external world (Yeo, 2003, p. 297). Malin 
et al. (1996) found that Aboriginal children were discouraged from exploration before they were 2 years of age; and that children younger than 2 years were more often carried than allowed to crawl or walk. Older children were encouraged to be self-reliant, while also looking out for other children and siblings. This suggests that peers and multiple caregivers may act as their secure base. Hamilton's (1981) research appears to support this suggestion. While adult caregivers still indulged children and gave them what they wanted beyond an approximate age of 2 years, no special effort was made to anticipate or structure their children's wants or needs. Self-reliance in an Aboriginal child may serve the best interests of the child within the Aboriginal community and may not be an indication of neglect. In addition, self-reliance and children's peer support of each other may not mean that caregivers are unaware of their children's actions. For instance, Aboriginal carers may also use non verbal gestures to attract a child's attention, of which a non Aboriginal person may be unaware.

Research has demonstrated that security, sensitivity, and competence are expressed differently in remote, regional, and urban Aboriginal communities when compared with the Western model. When considering the care and protection needs of an Aboriginal child, child protection practitioners need to assess the attachment relationship between Aboriginal infants, children, and their caregivers according to the cultural parameters and values of their clients, in order to be in a position to reflect on the suitability of the assessment method. Examples derived from Yeo (2003), Malin et al. (1996), and Hamilton (1981), which demonstrate how behaviours of Aboriginal children and their caregivers could be misconstrued include the following:

- Eliciting distress from an infant in order to assess a caregiver's response may not facilitate assessment of the Aboriginal caregiver's sensitivity if the cultural norm is to minimise infant distress before it occurs, rather than respond to it afterwards;

- An infant or young child seeking out multiple caregivers for care and even breastfeeding, or seeking out peers, may be misconstrued as indiscriminate attachment;

- A young child less than 2 or 3 years of age, who does not exhibit exploratory behaviour, may be wrongly assessed as insecure, if the community within which the child is growing up discourages exploration before this age;

- An Aboriginal mother's or caregiver's behaviour during caregiver-child interactions that is not directive may be incorrectly interpreted as poor attachment;

- A child who does not express negative emotion could be seen as having an avoidant attachment; however, the expression of negative emotion is often seen as disrespectful of elders in Aboriginal culture and, therefore, may be discouraged.

These are examples of where assessments may falter in relation to Aboriginal children and their caregivers. However, this is not to suggest that these examples indicate that 
a child is not being neglected, or that an attachment bond is secure in instances when it may not be. My argument is that an assessment needs to take particular cultural expressions of security, sensitivity, and competence into consideration, and should also take into account the context of multiple caregivers, the wider family and community, and the cultural values of the child and caregivers.

\section{Aboriginal Perspectives}

\section{Culturally Competent Caregiving in an Aboriginal Context}

In the previous section, links between contemporary Aboriginal child-rearing practices and Western theories of child nurturance were explored. Consistent with a "both ways" approach, alternative perspectives from Indigenous Australian cultures will now be examined. One such perspective can be found in the Central and Western Desert regions of Australia. Aboriginal languages of these desert regions reveal ancient and deeply nurturing values (McCoy, 2008; Myers, 1986; Priest et al., 2007). The words "kanyini" (in Luritja and Pitjantjatjara), "mardarni" (in Warlpiri), "kanyininpa" (in Pintupi), and "kanyirninpa" (in Kukatja), all languages from the Central and Western Deserts of Australia, have been translated by Myers (1986) from the Pintupi language as "holding, looking after, nurturance".

Myers (1986) referred to the Pintupi term "kanyininpa" in different nurturing circumstances from childhood and into adulthood. For instance, it is used in the term "kanyinu yampungka", which describes a child being breastfed, and implies security, protection, and nourishment. It is also present in terms describing the moral order of Pintupi culture, such as in the "tjukurrpa" (dreaming), which sets out the code for traditional Aboriginal desert peoples' life, including the rearing of children and young people. Through the tjukurrpa, the whole community is "held" by the dreaming.

Unlike Western attachment theory, there is an expectation that "holding" relationships will change over time. For example, the holding relationship is highly significant in the life of boys in late childhood. At this stage, boys leave the holding relationship of women and enter into the holding relationship provided by men. The older men guide them in a period of instruction, through authority and relatedness, and initiate them into adulthood (Myers, 1986). Myers maintained that this relationship, in the ceremonial context of initiation, was the strongest and most

\footnotetext{
${ }^{1}$ I have used the Pintupi word 'kanyininpa' as used by Myers (1986) in most headings unless directly referring to a particular author's use of the word, such as in the case of McCoy's (2007) reference to Balgo Mission using the Kukatja word "kanyinirpa". In my explanation of these terms I have referred to the Pintupi word "kanyininpa", the Kukatja word "kanyirninpa", and the Pitjantjatjara word "kanyini" strictly according to the word use of the authors I have cited. These words have similar meanings in each language. A number of other Indigenous words from these languages have also been used; the spelling of these words in this paper varies according to which language is being used as well as the cited author's use of spelling. Some spelling has changed over time, such as the use of "jukkurpa", where the " $j$ " has more recently been replaced with "tj". However, one of the authors cited in this paper used the former spelling of this word.
} 
powerful way in which older people showed their care, not only for these young men but for the whole recreation of desert life and culture from generation to generation.

\section{Kanyininpa and Attachment}

Although kanyininpa can be understood as an Aboriginal form of attachment, it must also be seen more broadly as embracing attachment to kin, as well as to community and to land, and incorporating a code for living socially, spiritually, physically, and morally. Kanyininpa was necessary for Central and Western Desert societies to be secure, and to develop social, spiritual, physical, and moral competence. It was not only related to children and their carers but to the whole of community relationships. The Warrki Jarrinjaku Aboriginal Child Rearing Strategy Project Team (2002) provided Pitjantjatjara and Luritja language meanings for four linked values in these desert societies. One of these values is "kanyini", the Pitjantjatjara and Luritja equivalent to the Pintupi "kanyininpa".

The four linked values of waltja, ngura, tjukurpa, and kanyini (Pitjantjatjara and Warlpiri languages) provide a view of the centrality of nurturance and the connectedness of the social, spiritual, physical, and moral order of desert society. "Waltja" may be translated as "family" but has a broader meaning than the Western notion of family. It includes anyone who has shared in one's nurturance. This relationship includes both people and animals. "Ngura" can be one's camp or home as well as the wider sense of a geographic area as ngura. One's ngura is a place of belonging, and the place where connections between people and one's ancestors are made. It is a source of protection and enjoyment and a provider of economic, social, and religious or spiritual fulfillment. The tjukurpa (the dreaming) outlines the creation of landforms, animals, vegetation, and ancestral spirits in one's ngura and beyond, according to ancestral activities. Aboriginal people have a relationship with their ngura through these connections and children learnt about them as they walked through the land, as well as in stories, dance, and song. Tjukurpa is the basis for all codes of behaviour and relationships between people, places, animals, and social organisation. Ancestral beings in the tjukurpa established the codes of behaviour that have been passed on to each generation including kanyini. Children belong to the tjukurpa from conception and learn the ways of being through stories, ceremonies, dance, art, and songs: "It was as a child that I began to learn and carry it on [jukurrpa, the Law]... We are holding it, we are still looking after it ...our understanding continues forever. We keep the Law eternally" (Molly Nungurrayi, translated from Warlpiri in Vaarzon-Morel, 1994, cited in Priest et al., 2007). Kanyini, according to Priest et al., means having, holding, keeping, looking after, minding, managing, and refers to how all connections, relationships, traditions, place, Dreaming, and Law are held together. It binds and holds together waltja, tjukurpa, and ngura (Pitjantjatjara and Warlpiri language dictionaries and Waltja Steering committee, personal commentary, in Priest et al., 2007). 
Figure 1 shows the relatedness of waltja, ngura, tjukurpa and that these are held within kanyini (holding) relationships of authority with nurturance, and relatedness with autonomy (Pitjantjatjara language), (after McCoy 2008, p. 21).

According to Myers (1986) and McCoy (2008), holding (kanyininpa and kanyirninpa respectively) was a sophisticated way in which desert society was maintained and nurtured. The ability to hold or nurture (kanyininpa) other people, country, and the spiritual aspects of culture was part of all aspects of life. Nurture (holding, kanyininpa) maintained society. It is important to understand that the ability and responsibility to hold and nurture infants, children, young people, and country was so highly valued, that authority was earned through ones' ability and responsibility to nurture or hold others.

\section{Kanyininpa and Colonisation}

The separation of Aboriginal children from families and communities that has occurred throughout the colonisation of Australia has been linked to the creation of intergenerational trauma in Aboriginal people (Atkinson, 2002; Gordon, Hallahan, \& Henry, 2002; Human Rights and Equal Opportunities Commission, 1997). The separation of Aboriginal people from various forms of kanyininpa, kanyinirpa or kanyini in the Central and Western Deserts, Pintupi, Kukatja, Luritja, and Pitjantjatjara languages respectively, and from waltja (family), ngura (home or homeland), and tjukurpa (ancestral dreaming stories that are also etched in land, in ritual, in song, and in dance) (Luritja and Pitjantjatjara languages) have been severely

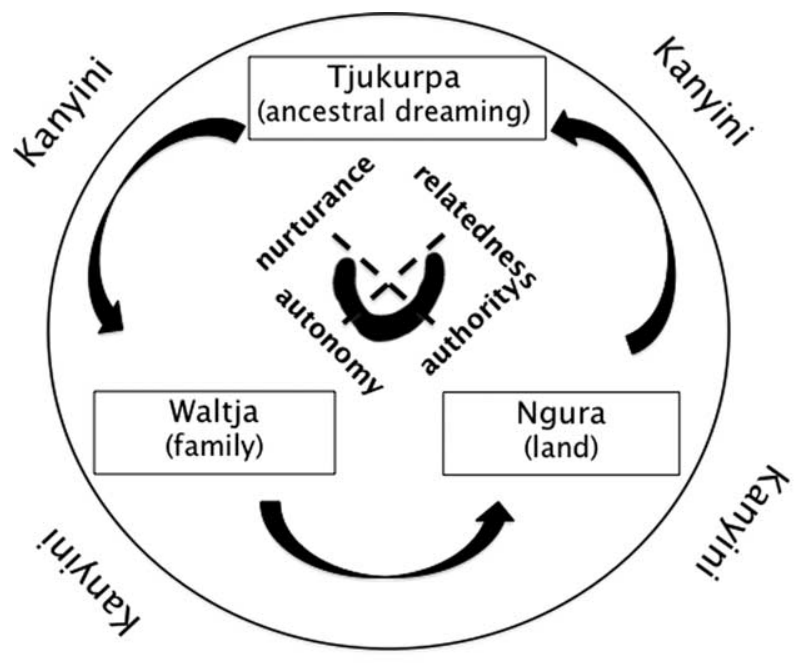

after McCoy (2008 p. 21)

Figure 1 Diagram showing waltja, ngura, tjukurpa and how these are held within kanyini (holding) relationships of authority with nurturance, and relatedness with autonomy (Kukatja language).

Source: adapted with permission from the author McCoy, 2008, p. 21. 
disrupted through the lack of understanding that non Aboriginal people have had for the ways these values and behaviours supported and maintained Desert societies. According to Atkinson (2002) and Gordon et al. (2002), psychological and physical suffering across generations has contributed to the internalised family and community violence that is now part of many Aboriginal communities.

\section{Attachment, Kanyirninpa (Holding), and the Separation of Aboriginal children at Balgo}

According to McCoy (2007), the removal of children from family and community care in Balgo Mission in the Western Desert was in opposition to the ideals of autonomy and responsibility contained in kanyirninpa (Kukatja language as used in Balgo). McCoy (2007) referred to Bowlby's theory of attachment in respect to Indigenous children from Balgo, who were separated from their parents in the 1950s and 1960s and placed in dormitories, and who described these experiences as traumatic. Despite the fact the children were not removed until they were 5 years of age, and they were still in close proximity to their community, the children missed out on the continuation of a traditional holding relationship. The values within kanyirninpa were unable to be exercised, expressed, or experienced as the children grew up. The dormitory experience undermined the social meanings and the creation of a social self in relation to others for these children, it separated the children from values and knowledge that were critical for developing social and emotional responsibility, and it destroyed their belief in the safety of their world. A middleaged Aboriginal man from Balgo described what he missed most by living in the dormitories:

I supposed to be learning from my father when I was $10 \ldots$ or $9 \ldots$ or $8 \ldots$ during the ceremonies they had in the camp with women folks and all. Well the man that do their dancing, well you'll see the one little fella behind. . that was when women do their dancing... same time... well I missed out that one. (McCoy, 2007, p. 61)

This man was describing knowledge that is embodied and only possible to receive through physical and social acts. "Dancing upon the land, using his body, being in the company of other men and women, all provided an important social and cultural context for learning about himself his culture and heritage" (McCoy, 2007, p. 61). As an older man, expected to be competent in guiding his community in decision making and traditional law, he expressed the difficulties he has with this role, as a result of missing out on cultural learning and holding relationships. Atkinson and Swain (1999) similarly argued that the removal of generations of Aboriginal children from families and communities in Victoria has denied these separated children the opportunity to bond with parents, to experience their love and acceptance, and has additionally damaged the confidence of Indigenous adults to parent their own children. Yeo (2003) also found that the safety of secure attachment had been eroded through discrimination and the impact of the "stolen generations". 
If non Aboriginal people can understand the past separation of Aboriginal children from family and community in relation to attachment theory, and see the deep importance and sustaining nature of kanyinirpa, we may be able to glimpse how wounding it has been for Aboriginal people to be removed from this form of nurturance, or have this nurturance severed or weakened.

\section{Kanyininpa (Holding) in Contemporary Aboriginal Societies}

Despite extreme difficulties and disruptions to the traditional form of kanyininpa or holding, it is still practiced by Aboriginal people in the Central and Western Deserts. Evidence suggests that aspects of contemporary Aboriginal mothering are also based on traditional practices (Atkinson \& Swain, 1999; Malin et al., 1996; Penman, 2006). There have also been recent attempts to reinforce traditional forms of child-rearing. The report "Pipirri Wiimaku: For the little kids": Innovative Child Care Report" (Waltja Tjutangku Palyapayi Aboriginal Corporation, 2001) documented how senior Aboriginal women initiated and conducted their own research into traditional forms of child rearing in response to the weakening of traditional child-rearing practices. This research was conducted with the assistance of Waltja Tjutangku Palyapayi Aboriginal Organisation, (commonly referred to as Waltja). ${ }^{2}$ The four principles of waltja, ngura, tjukurpa and kanyini (Pitjantjatjara) were identified by senior Aboriginal women in Central Desert communities as central to "growing up" their children and they now underpin the child-rearing strategies of Waltja. The documentation of childrearing practices in the Pipirri Wiimaku Report formed the basis of the Warrki Jarrinjaku Aboriginal Child Rearing Strategy (Warrki Jarrinjaku Aboriginal Child Rearing Strategy Project Team, 2002), a collaboration between senior Aboriginal women of the Central Desert, Waltja, and the Australian Government Department for Families, Housing, Community Services, and Indigenous Affairs.

Atkinson and Swain (1999) argued that Koorie mothering continues to be based on traditional practices, but has been adapted to contemporary situations within redefined gender relations, which have occurred because men in Indigenous society have lost the authority and position that they held in traditional society, having been replaced by the authority of the State. This is particularly noteworthy if we consider that men held highly nurturing roles within traditional societies. Most of the women participants in this research did not have a husband present for reasons such as high incarceration rates and higher death rates for Koorie males than for women, and a high breakdown of cross-racial relationships. Atkinson and Swain's research indicated that women's roles have been less disturbed than men's roles, and that Koorie identify in the contemporary extended Koorie family was maintained and nurtured by women. They also found that multiple mothering was common, and included women who were not biologically mothers who also provided nurturance to children, as well as forming a network of support for women.

\footnotetext{
2 The Waltja Tjutangku Palyapayi Aboriginal Organisation is a community-based organisation working with families in Central Australia.
} 
Research into a Nunga Aboriginal woman's parenting in Adelaide conducted by Malin et al. (1996) reflected some of the Anbarra child-rearing practices of traditional Aboriginal cultures observed and recorded by Hamilton (1981) and Berndt and Berndt (1981). The Nunga woman nurtured and encouraged her children to be independent, self-reliant, and to have knowledge of their Nunga culture and its commitment to family and kin. Self-reliance and independence were expressed in the way the children were allowed to play and run around as they wished before they sat down to eat. The children themselves determined how much was sufficient to eat. Care for family members was expected of older children towards younger children, evidenced when older children made sure the toddler was safe around play equipment and public conveniences, rather than the mother attending to the toddler's safety. This independence and care had indirect influence and control from the Nunga mother through storytelling meant to communicate a value-laden message, through selective attention or intervention in order to discipline the children, and through behaviour modelling. However, this was within a relationship of greater equality than may be experienced in relationships between non Aboriginal Australian children and adults. Penman (2006) reviewed the values the Nunga woman was teaching her children and suggested these were the traditional practices and values from the Central and Western Deserts, as outlined by Warrki Jarrinjaku Aboriginal Child Rearing Strategy. According to Penman, the capacity for these values and practices to flourish again still exists.

\section{The Role of Men in Kanyininpa}

There is little available literature regarding the role of Aboriginal men in the nurturance of children and young people. In the two contemporary urban examples of Nunga and Koorie mothering, the role of men in children's lives is missing. Atkinson and Swain (1999) suggested that Aboriginal Koorie men have been "robbed of the authority and position which they had held in traditional society without being able to find a parallel status in the new order". The Warrki Jarrinjaku Aboriginal Child Rearing Strategy Project Team (2002) discussed the need for more research into Aboriginal men's roles in child rearing. In the examples of traditional parenting, Hamilton (1981) recorded that Pitjantjatjara men of the Western Desert carried small children, talked and sang to them, told them stories, and even cooked special food for them. Myers (1986), Hamilton (1981), Berndt and Berndt (1981) and McCoy (2008) have all shown that in traditional Aboriginal societies, men's roles were highly significant in late childhood, when boys left the holding care of women, and were taken into the holding care of older men in a profound way.

Contemporary examples from Western and Central Desert societies have been described by McCoy (2008), where the holding role can be observed within the lives of men and boys. One example is that of football carnivals in Aboriginal communities. These carnivals, and the training and preparation that occur before they take place, bear some relationship to social corroborrees. McCoy described how 
these carnivals typically involve older men making preparations and travelling with young men for long distances for intercommunity games, and in the process instructing them in appropriate behaviours with other communities and distant kin. Similarly, important ceremonies, some of which still occur, also involve travelling to distant communities, with young men under the care and authority of older men, meeting distant relatives, and becoming part of a wider community. While traditional ceremonies involved ritual activities of significance that are not present in football carnivals, the sense of care and being under the authority and instruction of older men persists. This is one way in which men in contemporary desert societies in Australia maintain holding relationships, develop relationships with extended family, and learn how to be men who have authority through their nurturing relationships. This paternal relationship does not apply only to a biological father but also to fathers, brothers, and anyone who has looked after a younger man or boy in a nurturing way: "A man becomes 'really father' when he looks after you" (Myers, 1986, p. 212).

\section{Conclusion}

Culture, family, and community shape particular ways of nurturing children to grow into emotionally competent adults, who can in turn sustain intimate relationships and nurture their own children. The ways in which Aboriginal people have traditionally nurtured their infants and children may differ from western models but the Aboriginal ways do include the universal components of security and protection. Attachment theory provides a framework for defining the relationship between a primary caregiver and an infant or young child to determine whether a healthy emotional bond exists between them. However, it needs to be used in a culturally appropriate way with Aboriginal people. There are many parallels between traditional Aboriginal nurturance and the Western theory of attachment, but there are also important differences that need to be kept in mind. The traditional form of Aboriginal nurturance was very broad and included nurturance and attachment to kin, to community, and to land, and provided Aboriginal people with a strong code for living socially, spiritually, physically, and morally. The example of kanyininpa (holding) from the Western and Central Deserts demonstrates how this Indigenous form of nurturance provided security, protection, and guidance within a sophisticated network of relatedness that regarded the holding relationship so highly that one's ability to "hold" others was integral to the functioning, maintenance, and sustenance of Aboriginal society from generation to generation. Research has shown that aspects of traditional nurturance and child rearing are still in existence in contemporary Aboriginal cultures in Aboriginal communities across Australia, highlighting the probability that this highly nurturing behaviour existed in traditional societies throughout Australia.

The current high levels of child abuse and neglect in Aboriginal communities reflect profound changes since colonisation, including changes to traditional 
nurturing practices, which in many cases have traumatised generations of Aboriginal people and affected their abilities to nurture children successfully. Many Aboriginal communities are now attempting to renew traditional models or adopt more contemporary models and values of nurturance that support children and families.

Studies across Australia have also shown that many of the differences in caregiving behaviours and expressions of sensitivity, sociability, regulation of affect, selfexpression, and competence found in traditional Aboriginal cultures have been retained in contemporary Australian urban, regional, and remote Aboriginal communities. Focusing on these differences can show how child protection assessments could be conducted and interpreted with respect to Aboriginal caregivers and children. Some of the differences have been discussed in this paper, including: the widespread practice of multiple mothering and the consequent possibility of attachment to a number of "mothers"; responses to infants that are different from Western ways, such as the minimisation of distress before it occurs; discouragement of exploratory behaviour in very young children so that a child may not be using a caregiver as a secure base for exploration; children over 2 or 3 years of age being more self-reliant than the average non Aboriginal child; caregivers and children sharing more nonverbal gestures in their communication; and the lack of expression of negative emotion in Aboriginal children towards older people, including caregivers, which may be an indication of respect rather than an indication of avoidant attachment.

The ways in which child protection assessments relate to Aboriginal children, caregivers, and community values need to be more clearly understood by practitioners and policy makers so that decisions made will assist Aboriginal children and families. It is necessary for non Aboriginal people to listen with "open ears" to the views of Aboriginal child protection workers and Aboriginal families and communities, to continually consider their own values and practices, and reflect on the applicability of these to Aboriginal caregivers and children. In this way, it may be possible to cocreate Aboriginal child and family welfare systems with the capacity to alter the course of Indigenous child, family, and community welfare for the better.

\section{References}

Atkinson, J. (2002). Trauma trails. North Melbourne, Victoria: Spinifex Press.

Atkinson, S., \& Swain, S. (1999). A network of support: Mothering across the Koorie community in Victoria, Australia. Women's History Review, 8, 219-230.

Berlyn, C., \& Bromfield, L. (2010). Child protection and Aboriginal and Torres Strait Islander children. National Child Protection Clearinghouse Resource Sheet. Melbourne, Victoria: Australian Institute of Family Studies.

Berndt, C., \& Berndt, R. (1981). The world of the first Australians: Aboriginal traditional life past and present. Canberra, ACT: Aboriginal Studies Press.

Bessarab, D., \& Crawford, F. (2010). Aboriginal practitioners speak out: Contextualising child protection interventions. Australian Social Work, 63, 179-193.

Bowlby, J. (1969). Attachment. (Vol. 1, Attachment and loss). Harmondsworth: Penguin. 
Brown, D., Hawkins Rodgers, Y., \& Kapadia, K. (2008). Multicultural considerations for the application of attachment theory. American Journal of Psychotherapy, 62, 353-363.

Gordon, S., Hallahan, K., \& Henry, D. (2002). Putting the picture together: Inquiry into response by government agencies to complaints of family violence and child abuse in Aboriginal communities. Perth, WA: Department of Premier and Cabinet, State Law Publisher.

Hamilton, A. (1981). Nature and nurture. Canberra, ACT: Australian Institute of Aboriginal Studies.

Human Rights and Equal Opportunity Commission. (1997). Bringing them home. Report of the National Inquiry into the Separation of Aboriginal and Torres Strait Islander Children from their Families. Sydney, NSW: Human Rights and Equal Opportunity Commission.

Jordan, B., \& Sketchley, R. (2009). A stitch in time saves nine: Preventing and responding to the abuse and neglect of infants, Child Abuse Prevention Issues, 30. Retrieved April 30, 2011, from www.aifs.gov.au/nch/pubs/issues/issues30/issues30.html

Malin, M., Campbell, K., \& Agius, L. (1996). Raising children in the Nunga Aboriginal way. Family Matters, 43, 43-47.

McCoy, B. (2007). "They weren't separated": Missions, Dormitories and Generational Health. Health and History, 9, 48-69.

McCoy, B. (2008). Holding men: Kanyirninpa and the health of Aboriginal men. Canberra, ACT: Aboriginal Studies Press.

Minuchin, P. (2002). Cross-cultural perspectives: Implications for attachment theory and family therapy. Family Process, 41, 546-550.

Myers, F. R. (1986). Pintupi country, Pintupi self: Sentiment, place, and politics among Western Desert Aborigines. Washington, DC: Smithsonian Institution Press.

Penman, R. (2006). The growing up of Aboriginal and Torres Strait Islander children: A literature review: Canberra, ACT: Australian Government, Department of Families, Housing, Community Services and Indigenous Affairs.

Perry, B. D. (2001). Bonding and attachment in maltreated children: Consequences of emotional neglect in childhood. Retrieved October 18, 2010, from www.ChildTrauma.org.

Posada, G. (2002). Child-mother attachment relationships and culture. American Psychologist, 56, 821-830.

Priest, K., King, S., Nungarrayi Brown, W., Nangala, I., \& Nangala, M. (2007). Warrki Jarrinjaku Jintangkarmanu Purananjaku "Working together everyone and listening": Aboriginal child rearing in remote Central Australia. Canadian Journal of Native Education, 30, 61-74.

Rothbaum, F., Weisz, J., Pott, M., Miyake, K., \& Morelli, G. (2000). Attachment and culture. American Psychologist, 55, 1093-1104.

van Ijzendoorn, M., \& Sagi, A. (1999). Cross cultural patterns of attachment: Universal and contextual dimensions. In J. Cassidy \& P. Shaver (Eds.), Handbook of attachment: Theory, research and clinical applications (pp. 434-465). London: Guilford.

Waltja Tjutangku Palyapayi Aboriginal Corporation. (2001). Pipirri Wiimaku: "For the little kids": Innovative Child Care Report 2000-2001. Alice Springs, Northern Territory: Waltja Tjutangku Palyapayi Aboriginal Corporation.

Warrki Jarrinjaku Aboriginal Child Rearing Strategy ACRS Project Team. (2002). Warrki Jarrinjaku Jintangkamanu Purananjaku: Working together everyone and listening: Aboriginal child rearing and associated literature. Canberra: Department for Family and Community Services.

Yeo, S. (2003). Bonding and attachment of Australian Aboriginal children. Child Abuse Review, 12, 292-304. 